\section{A associação entre a hepatite $B$ e a esquistossomose mansônica: uma falácia ecológica}

Há poucos estudos de campo sobre a associação entre a hepatite B e a esquistossomose mansônica no mundo. Neste estudo avaliaramse os aspectos epidemiológicos, clínicos e ultrasonográficos da associação entre a hepatite B e a esquistossomose. Duas populações semelhantes foram selecionadas para o estudo: 1) Queixadinha, área endêmica para esquistossomose, constituída de 693 indivíduos, e 2) Capão, área não endêmica para esquistossomose, constituída de 515 habitantes. Realizou-se o censo das populações e todos os indivíduos submeteramse a exame clínico, exame parasitológico das fezes, ultra-sonografia do abdome e marcadores sorológicos da hepatite $\mathrm{B}$ (AgHBs, antiHBs e antiHBc), anualmente, no período de 1994 a 1997. Em Queixadinha, os marcadores sorológicos de hepatite $B$ (MSHB) estiveram presentes em $32,1 \%$ das crianças até um ano de idade e atingiram pico de $68,7 \%$ na faixa etária dos 15 aos 19 anos. Na área controle não foram encontrados os marcadores sorológicos na população de crianças menores de cinco anos de idade e a prevalência manteve-se abaixo de $5 \%$ até os 19 anos de idade. Nessa área, a prevalência máxima ocorreu em adultos após os 45 anos. Na população de Queixadinha, o AgHBs foi identificado no soro de $9,4 \%$ dos indivíduos examinados contra $1,4 \%$ na área controle (OR = 4,98; IC95 = 3,7-6,7). Os resultados obtidos mostraram que as curvas de prevalência da esquistossomose e de MSHB se assemelham em Queixadinha, enquanto a curva de MSHB na área controle seguiu o padrão encontrado em regiões de baixa endemicidade para a hepatite B. Na área endêmica para esquistossomose não houve diferença em relação a presença ou não de MSHB, quando os indivíduos sem esquistossomose foram analisados em relação às seguintes variáveis: sexo, raça, idade, dados antropométricos e nutricionais, alcoolismo, icterícia, injeções, transfusões de sangue, hemocomponentes e hemoderivados, sangramento digestivo, internações, manipulação dentária, esplenomegalia

\section{Association of hepatitis B and schistosomiasis: an ecological falacy}

Field-based studies on the association of hepatitis $B$ and schistosomiasis are rather few. The aim of this study was to evaluate, in an endemic area for schistosomiasis, the epidemiological, clinical and sonographic features of the interaction between hepatitis $B$ and schistosomiasis mansoni. Two equivalent populations have been selected for this study: 1) Queixadinha, hyperendemic for schistosomiasis with 693 individuals, and 2) Capão, nonendemic for schistosomiasis with 515 inhabitants. All individuals in both areas were submitted to clinical and parasitological examinations, abdominal sonography and had their sera examined for serological markers of hepatits $B$ (HBsAg, antiHBs, antiHBc), yearly, from 1994 to 1997. In Queixadinha the serological markers of hepatitis $\mathrm{B}$ were found in $32.1 \%$ of the children up to 1 year-old and reached a peak of $68.7 \%$ in the age range of 15 to 19 years. In the control area, serology for hepatits $B$ was negative in children younger than 5 years, and the presence of serological markers of hepatitis $B$ remained below $5 \%$ in the sera of the adolescents up to 19 years of age. In the nonendemic area the prevalence of hepatitis $B$ was highest in adults over 45 years. In the population of Queixadinha HBsAg was identified in the sera of $9.4 \%$ of the individuals against $1.4 \%$ in the control area $(\mathrm{OR}=4.98 ; \mathrm{Cl}=$ 3.7-6.7). A similar pattern of distribution of hepatitis B and schistosomiasis was observed in Queixadinha, whereas in Capão hepatitis B presented a pattern of distribution that was not different from the one described for populations living in areas of low endemicity for hepatitis B. No significant difference was observed in the group without schistosomiasis, living in Queixadinha (endemic for schistosomiasis) in regard to the presence or absence of serological markers of hepatitis B when the following variables were examined: gender, race, age, antropometry, nutritional status, alcohol abuse, jaundice, history of receiving transfusion of blood or blood derivatives, intramuscular injection, 
e fibrose hepática ao ultra-som. Nenhuma diferença foi observada também quando as mesmas variáveis foram estratificadas para o grupo negativo para hepatite $B$ (com ou sem EM). Os índices de cronicidade da infecção pelo vírus da hepatite B foram semelhantes entre as populações de Queixadinha e de Capão $(8,1 \% \times 7,3 \%)$ e entre os grupos com e sem esquistossomose em Queixadinha (8,7\% x 7\%). A prevalência da esquistossomose apresentouse uniforme nas áreas estudadas em Queixadinha. Verificou-se, ao contrário, distribuição heterogênea dos MSHB nas mesmas áreas. Registrou-se alta prevalência de hepatite B e de esquistossomose em Queixadinha, porém, uma doença não predispõe à outra, ao passo que observou-se nítido agrupamento geográfico da hepatite B. Nenhum fator de confusão ou de interação foi evidenciado na área estudada. A associação entre a esquistossomose e a hepatite B em Queixadinha representa uma falácia ecológica. dental manipulation, splenomegaly and liver fibrosis on ultrasound. No difference was also described when the same variables were stratified in the group negative for hepatitis $B$ (with or without schistosomiasis). The prevalence of chronic carriers of HBsAg was not significantly different in Queixadinha and Capão (8.1\% x $7.3 \%$ ); no difference was also observed (as chronic carrier state is concerned) between those with or without schistosomiasis in Queixadinha. The distribution of schistosomiasis was uniform in the 6 studied areas of Queixadinha whereas a heterogeneous distribution of hepatitis $B$ was found in the same areas. A high prevalence of hepatitis B and schistosomiasis was found in Queixadinha but schistosomiasis was not a predisposing cause for hepatitis B. Meanwhile hepatitis B, in Queixadinha, was found to be distributed in geographic clusters. No confounding or interaction factors have been shown between hepatitis B and schistosomiasis in the studied area. The association of hepatitis $B$ and schistosomiasis in Queixadinha seems to represent an ecological falacy.

José Carlos Serufo

Tese apresentada à Faculdade de Medicina da

Universidade Federal de Minas Gerais para obtenção do Título de Doutor.

Belo Horizonte, MG, Brasil, 1997 